\title{
Deshamanya Dr. PR Anthonis
}

\author{
Fellow of the Royal College of Surgeons, England, Order of the Sacred Treasure of Japan
}

On 21 January 1911 was born a child destined to become a doctor whose brain and hands saved the greatest number of lives in Sri Lanka in the 20th century. The child was named Romiel Anthonis. He came to be known to fame as Dr. PR Anthonis, the surgeon of the rulers and of the common people of this country. Judged by the criterion of preventing the greatest number of deaths by the dexterous use of one's hands, Dr. Anthonis must surely be reckoned the greatest doctor who operated in this country, in the past century, if not, indeed, in the past millennium. We rejoice in the fact that he is still so full of life. He is almost certainly the last survivor among the great and the good in our profession who flourished and peaked in the 20th century.

\section{School record}

In the early decades of the 20th century there was only one road open to the children of "nobodies" to compel at least the unwilling attention of "somebodies" whose loyalty to the British rulers had been amply rewarded by grants of landed property and, even more important, social recognition by the rulers. In such a context, the only road open to him was the arduous one of scholastic achievement. As it happened, when I asked Dr. Anthonis the leading question, "Sir, what do you think made you tick?" Without a moment's hesitation he rattled off from memory his primary, secondary and medical school record. Indeed, detailed accounts of school prize-givings were published in the leading newspapers of that time. In Dr. Anthonis's scrap book there is a clipping from the Morning Leader of 11 December 1926. It is a report of the first prize-day at St. Joseph's College, South (which later metamorphosed into St. Peter's College, Colombo 4). It says, "There were tremendous cheers when young PR Anthonis walked up to the platform to receive five prizes" (General Proficiency, Latin, French, Mathematics, and Science in primary school). In secondary school he won all but one of the nine available prizes. (As a Buddhist in a Roman Catholic school he was not eligible to compete for the prize in Religious Knowledge). In due course he was appointed the Senior Prefect of the school.

\section{Professional record}

His school career's promise was fulfilled in Colombo Medical School. He came first in the first class in all professional examinations, winning gold medals for surgery, forensic medicine and pathology. What he remembers with special pride is the fact that he won the Government Diploma Medal awarded to students who come first in the final professional examination provided they have attained a very high level of competence. When he won that Medal in 1936 he was the only future surgeon to have done so during the 11 years that had elapsed after Dr. MVP Peiris won it in 1925.

World War II interrupted the careers of many medical professionals. It was after the war that Dr. Anthonis went to England to obtain specialist qualifications in surgery. He has preserved records which show that when he, with eight other Ceylonese, sat the final FRCS Examination in 1947, he was the only one who was successful. He became the first Ceylonese surgeon to sail through the primary and final examination for the Fellowship of the Royal College of Surgeons of England (FRCS) without a single examination mishap. He returned to Ceylon and was duly appointed Consultant Visiting Surgeon at the General Hospital in 1947 and served in that capacity until he retired on 21 January 1971.

\section{Ideal of service}

Before writing this I had the pleasure and privilege of spending an evening with him at his elegant home. I had savoured his marvellous collection of art and rare books on previous occasions. That evening I focused on his accumulated clinical records. He had done two surgical operations that morning. I figured out that during his 70 years as a doctor, he must have performed at least a hundred thousand surgical operations. The records show that no less than 38000 of these have been done after his retirement from government service in 1971. With exemplary zeal and dedication he has been performing for 70 years, what I consider to be the proper duty of a doctor, which is patient care and caring for patients. Fortunately for the poor and rich alike in Sri Lanka, the guiding principle of his professional life has always been the ideal of service. And it has been greatly, gratefully and effusively appreciated by any number of people. To document fully all the unsolicited tributes he has received would require an entire issue of the $C M J$. Because browsing through these tributes is manifestly a source of great happiness to him, they cry out for citation in a $C M J$-commissioned essay of the celebrate-the-great-before-they-die genre.

\section{Unsolicited tributes}

Mr. ERSR Coomaraswamy, the eminent legal scholar, distinguished lawyer and maverick politician was moved to write a tribute in nine quatrains to Dr. Anthonis on the third day after Dr. Anthonis had performed a surgical operation on him. Its beginning and end are reproduced in full because they eloquently voice the common feeling of the public Dr. Anthonis served. 
"A man he is to all Sri Lanka dear,/A surgeon of the highest calibre,/An ageless wonder whose delightful hands/Have given life alike to rich and poor...

For how few men like him are ever born !/All reason more for us to bless that morn/And pray that God with added strength and years/Will bless him, who doth wipe away our tears"

Another unsolicited tribute came in 1981 from Tom Duthie, 70, an American from Pennsylvania who had developed a case of severe intestinal obstruction while on a visit to Sri Lanka. He had made what he called "a miraculous recovery" after Dr. Anthonis had resected some five feet of gangrenous bowel. Back in the United States he went so far as to write in a local newsletter: "In retrospect I am glad that the necessity for this [operation] occurred in Sri Lanka rather than the United States. How could I have fared better? The loving care and attention I received from doctors, nurses and other staff was superb..." His family physician Dr. William J Gilhool, a Professor of Internal Medicine, wrote a two-page letter to Dr. Anthonis thanking him for his "excellent diagnostic acumen, therapeutic intervention and pleasant management of Mr. Duthie."

On a visit to London's famous Hospital for Sick Children at Great Ormund Street, Dr. Anthonis had had the opportunity of sharing his vast practical surgical experience with Professor AW Wilkinson to operate on a complicated case. Dr. Anthonis proudly showed me an article by Professor Wilkinson sent to him with the inscription: "To Dr. Anthonis in Respect and Admiration".

There have been literally tens of thousands of people, among them Governors General, Presidents, Prime Ministers, Mahanayakes, Archbishops, Ambassadors, singers, film stars, bankers, professors, doctors, lawyers and hewers of wood and drawers of water who believed that they got new leases of life because of Dr. Anthonis' surgical skills. Wading haphazardly through the incredible volume of his memorabilia, I caught glimpses of glowing tributes from Dr. RL Spittel (surgeon), Dr. Sivasubramaniam (ophthalmologist), Dr. Geri Jayasekera (surgeon), Sunil Santha (musician), Professor Savitri Gooonesekere (Vice Chancellor), Professor AH Sheriffdeen (surgeon), Professor BN Tandon (All India Institute of Medical Sciences) and Dr. Ifthikar Ismail (industrialist) among many others.

\section{Household name}

Dr. Anthonis probably reached the pinnacle of his surgical career when it fell to his lot to perform a 6-hour surgical operation in a desperate bid to save the life of the then Prime Minister Mr. SWRD Bandaranaike. Mr. Bandaranike had been repeatedly shot at point blank range at his mansion in Rosmead Place, Colombo in the morning of 25 September 1959. The heroic surgery itself had been successful, but 21 hours after the operation, on the next day, the Prime Minister succumbed to massive pulmonary embolism.
In due course came the predictable honours and fellowships and honorary degrees. He was the first recipient ever of the highest national honour of independent Sri Lanka, namely, the tile of Deshamanya. The College of Surgeons, the College of Physicians and the College of Obstetricians and Gynaecologists bestowed their fellowships on him. He was appointed Chairman of the Sri Lanka Medical Council in 1981. He was awarded the degree of Doctor of Science (honoris causa) by the University of Colombo. He was appointed Chancellor of the University of Colombo in 1981 and was routinely reappointed to serve a total period of some 22 years. When he eventually retired from that position in 2003 at the age of 92, the President of the Republic HE Chandrika Bandaranaike Kumaratunga officially felicitated him "in appreciation of his unparalleled service to the health of the nation". In 2005, the College of General Practitioners of Sri Lanka awarded him the title of "Pride of the Medical Profession".

Nor has the recognition of his surgical eminence been only in our island home. In 1968, the Royal College of Surgeons of England appointed him to their Board of Examiners for their primary fellowship examination. The Government of Japan conferred on him the Order of the Sacred Treasure, partly in recognition of his collaboration with eminent surgeons in Japan, and for his contribution to the furtherance of friendly relations between Japan and Sri Lanka.

\section{Versatility}

For a man with a single-minded devotion to the surgical care of patients which demands sustained intellectual energy, highly skilled manual work, and endless hours of professional activity, Dr. Anthonis has been remarkably versatile. He has been the Head of the Police Reserve Medical Corps. Way back in 1956, he was part of a small business team which started the first Insurance Training School in Sri Lanka. He has been a Founder Director of Seylan Bank. He has been the leader of a trade union of doctors. He is a collector of rare books and works of art. I have often been amazed by his knowledge of the history of our country. Whenever a historical subject is discussed, he will often supply a little known illuminating fact, such as the connection of the concept of hospitals with Buddhist culture. His concern for others compulsively drives him to find time to attend innumerable weddings, inductions, ceremonial openings, exhibitions and whatever else he is invited to as a special guest. His unfailing attendance at funerals has been a source of consolation to many bereaved people.

\section{Family background}

PR Anthonis saw the light of day as the second child of a biologically remarkable couple: Polwattearachchige Margaris Anthony Appuhamy and Hettiarachchige 
Engelthina Perera. They begot no less than 16 robust children and somehow managed to feed, clothe, shelter and educate the brood. They both lived to see their 80th birthdays and numerous grandchildren. Dr. Anthonis is proud of the fact that his family was poor but content, which was rich and rich enough. He remembers his parents with something like profound reverence. Exactly on his 32nd birthday, Dr. Anthonis married Lillian Ruby Perera and lived happily ever after until she began — as Dr. Anthonis believes — another cycle of samsaric existence a few years ago. As many of us know, she was a wonderful hostess. Their only offspring, Lal Anthonis, is a brilliant photographer, renowned for his passionate interest in our natural environment and wildlife.

\section{Perfect teacher}

For my part, I remember him best for the extraordinarily perfect teacher he was. He taught little but we learned much from him. I still remember how he taught us "the fallacy of composition", when what is true of a part is therefore believed to be true for the whole. Once during a ward class, on a suspected case of filariasis, I reasoned that it was logical to rule out the diagnosis of filariasis because a single standard test done on a drop of blood did not show the presence of parasites. He said, "I say, if you take a bucket of water from the sea, and find a fish in it, you can infer that there are fish in the sea. But if you do not find a fish in the bucket of sea-water, is it logical to conclude that there are no fishes in the sea?" Unlike inferior teachers, he was never abusive, humiliating, sarcastic or superior. In pupils who came under his influence, Dr. Anthonis inspired, as he did in me, a deep, enduring and admiring affection.

He is now going on his 95th year. I hope, but do not expect to be around to wish him many happy returns on his 100 birthday. I feel no compulsion whatsoever, to deliver a final judgement on him, here and now. I wrote this to set down the thoughts bubbling for expression in my head and heart, to be offered by courtesy of the $C M J$, "To Sir with Love".

Carlo Fonseka, Professor Emeritus, University of Colombo and University of Kelaniya, Sri Lanka.

\section{Ceylon Medical Journal Order Form}

Name (Prof/Dr/Mr/Ms)

Postal Address.

Email Address.

*Amount(USD) Cheque/Bank Draft No

Name and Branch of Bank.

Number of years of subscription.

Signature.

(Write Cheque or Bank draft in favour of "Ceylon Medical Journal A/C 0030330568 CU." Please type or fill form in block capitals, and post along with payment to Editors, Ceylon Medical Journal, Sri Lanka Medical Association, No. 6 Wijerama Mawatha, Colombo 7, Sri Lanka. Journals will be sent by ordinary Air Mail. Add USD $10 *$ per year for Registered Air Mail delivery)

*In USD or its equivalent in Pounds Sterling, Euros, or Australian, Canadian or Singapore Dollars. 